\title{
Development of a Subjective Well-Being Quaternary Scale in Consumption (SWB-QSIC)
}

\section{消費における主観的ウェルビーイング 4 類型尺度 (SWB-QSIC) の開発}

\author{
Yutaka Suishi ${ }^{* 1}$, Nozomu Takahashi ${ }^{* 2}$, Koichiro Taguchi ${ }^{* 3}$ \\ 武蔵野美術大学ソーシャルクリエイティブ研究所 \\ 水師 裕 \\ 株式会社クロス・マーケティング \\ 高橋 望 \\ 株式会社クロス・コミュニケーション \\ 田口 功一郎

\footnotetext{
${ }^{* 1}$ Musashino Art University Research Center of Social Creative, Japan, suishi.com@gmail.com

${ }^{* 2}$ Cross Marketing Inc., Japan, no_takahashi@cross-m.co.jp

${ }^{* 3}$ Cross Communication Inc., Japan, k_taguchi@cross-c.co.jp
}

\begin{abstract}
The purpose of this study is to develop a new way of measuring subjective well-being, incorporating 1) aspects of happiness and well-being that have been discarded in the West due to development of modern rationalism, and 2) aspects of consumption. After defining a conceptual model consisting of four perspectives: bricolage, engineering, serendipity, and lean, we developed the Subjective Well-Being Quaternary Scale in Consumption (SWBQSIC), based on the model. We then examined the relationship between the SWB-QSIC and a major subjective wellbeing scale, the Satisfaction With Life Scale (SWLS), developed by Diener, Emmons, Larsen and Griffin (1985). We also examined the relationship between the SWB-QSIC and the frequency of leisure time activities, as an actual consumer behavior. Our results may provide a different perspective to the current trend of marketing studies in Japan, which often follow the trends of subjective well-being studies in North America.
\end{abstract}

Keyword : Happiness, Bricolage, Engineering, Serendipity, Lean

要約 : 本研究の目的は, 西洋的な近代合理主義から捨象された幸福やウェルビーイングの側面および消費の側面を取り入れた新 たな主観的ウェルビーイングの測定尺度を開発することにある。本研究では，はじめにブリコラージュ，エンジニアリング，セ レンディピティ, リーンの 4 つの観点からなる概念モデルを提案した。次にこの概念モデルに基づき尺度項目の開発を行った。 開発された尺度には「消費における主観的ウェルビーイング 4 類型尺度（SWB-QSIC)」と名付けた。最後に，SWB-QSIC と主 要な既存の主観的ウェルビーイング尺度である Diener, Emmons, Larsen, and Griffin (1985) の開発した人生満足度尺度 (SWLS) との関連，ならびに，実際の消費者行動として余㗇活動の頻度との関連を吟味した。これにより，北米を中心とした主観的ウェ ルビーイング研究を翻訳して使用することの多い我が国のマーケティング研究の流れに対して，新たな視座を提供した。

キーワード : 幸福, ブリコラージュ, エンジニアリング, セレンディピティ, リーン

Information : Received 11 August 2020; Accepted 25 November 2020

\section{I.はじめに}

近年，マーケティングにおいて，幸福やウェルビーイ ング（well-being：以下, WB と表記）への関心が高まっ ている (e.g., Devezer, Sprott, Spangenberg, \& Czellar, 2014）。我が国でマーケティングの研究や実務に幸福や
WB を取り入れようとする際, 北米を中心とした心理学 や消費者行動研究の「科学的知見」を翻訳して利用する 場合が多いのではないだろうか。

しかしながら, 実際には近代合理主義に基づく科学的 アプローチから捨象されてきた WB の側面も存在する。 例えば東洋では, 孔子の説く五常（仁，義，礼，智，信） に示される関係的調和性，仏陀の説く解脱，無我に示さ 
れる平穏な心性が幸福な人の特徵とされてきた（Horige, 2019）。西洋的な近代合理主義に基づく尺度を翻訳して WB を測定する限りにおいて，近代合理主義からこぼれ 落ちるWB の側面を把握するのには，限界が生じるもの と考えられる。

当然,「近代化」された社会に生活している以上, 我々 は近代合理主義の枠組みからは逃れられない。しかしそ の枠組みの中にあることを自覚しつつも, 本研究では, 近代合理主義から捨象されたWB の側面とその側面に関 わる消費の側面を取り入れた新たな WB の測定尺度を提 案する。これにより，我が国のマーケティングにおける WB 把握への新たな視座を提供することを目指す。

\section{II. 先行研究と概念モデル}

\section{1. 近代合理主義からこぼれ落ちるウェルビーイング}

本研究では，幸福感を主観的に評価する主観的ウェル ビーイング (subjective-well-being：以下，SWB と表記) の視点から尺度開発を行う。心理学において，SWB は 「ある時点で，または長期にわたり，自分の人生をどのよ うに評価するか」（Diener, Oishi, \& Lucas, 2003）を意味 する。心理学では，SWB の視点から尺度開発が行われ， SWB の測定可能性が実証されてきた。しかしそのほとん どが北米など西洋圈での研究であり，日本におけるWB 研究は，その尺度を翻訳したものが多い。

こうした既存の SWB 尺度を使用して，同一の経済的 水準をもつ先進諸国と比較すると, 日本は一貫して SWB が低い場合が多いという（Uchida＆ Ogihara, 2012）。「欧 米で策定された物差しで日本の幸福度を測り，単純に平 均值を比較して日本の幸福度が低いと結論づけることは, 日本人の幸福感に寄与する指摘として十分たり得ない」 （Uchida \& Ogihara, 2012）のである。Kitayama（2012） は,「現在の欧米，特にアメリカのスタンダードは，とに かくポジティブで, 誤解を承知の上で喻えをだせば「ドー パミンが増えていればそれがよし」といわんばかりのも のであるが，まず，これを見直す作業から始める必要が ある」と指摘する。Oishi and Komiya（2012）は，特定の 文化で主観的幸福感と関連しない測定項目も含めて全体
を一絡げに比較してしまうことは，不当にSWB の「文 化差を“見出して”しまうばかりか，そのデー夕の意味 するところを解釈する機会も逸してしまうのではない か」と批判する。

\section{2. 作為的志向性と自然（じねん）的志向性}

近代合理主義の特徵として挙げられるのは, 理性を信 奉し, 分析的, 客観的, 量的に事象を把握せしむる思考 や態度であろう。これは，いわば複雑な自然（nature） や環境を複雑なままとらえるのではなく, 計量可能なモ デルによって，「分かりやすく」とらえる行為の様式であ るともいえる。我々の住む「近代」的な社会において， 計量可能なモデルからこぼれ落ちる複雑なものは, 黙殺 されがちである。実際，明治維新以降，我が国は西洋的 な近代化の道を辿ってきたため, こうした西洋的な近代 合理主義的な思考は馴染みの深いものだろう。しかしな がら, 近代合理主義的な思考からこぼれ落ちる側面に価 值を置く志向性が，同時に我が国には残存していると考 えることはできないだろうか。

例えば仏教用語には, 自然（じねん）という言葉があ る。「仏教では，自然を〈じねん〉と訓じて「自ら然る」 という意味に解する。人間の作為のない「そのまま」の 在り方が自然である」(Kimura, n.d.)。Kimura (n.d.) は, 自然（nature）と自然（じねん）を比較して以下のよう に指摘する。「明治以降，西洋語のネイチャー (nature) の翻訳語として「自然」が用いられる。この自然は人間 と対置するものとされる。しかし仏教が説いているよう に，人間は自然を超えた存在ではなく自然の一部である。 その人間が思い上がって科学技術を駆使して自然を破壊 する。一方で，意匠を凝らした盆栽や日本庭園に人工の 自然を見いだそうとしているのは，何と考えたらよいの だろうか」(Kimura, n.d.)。近代的な合理的思考は自然 （nature）に手を加え, 便利から心地良いかたちへと作為 的に作り変えるが，その反面，作り変えられる前の状態 に憧憬の念を覚えるのが人間のもつ複雑さでもある。

仏教の見方を手がかりにすれば，西洋の近代合理主義 的な見方に反する，もしくはそこからこぼれ落ちる，我 が国に打けるWB の志向性として，「自然（じねん）的 志向性」とでも呼べる心理傾向が残存している可能性が 
指摘できる。しかしそれと同時に，明治維新以降我が国 においても近代合理主義的な価值観が移入されているた め, 合理的思考 ·科学的思考に基づく「作為的志向性」 とでも呼べるWB の心理傾向が並存すると考えられる。

本研究では, 作為的志向性を「条件や結果などを操作 できるという前提に立ち，目標設定された予測可能な価 值を意図的に獲得する志向性」と定義する。また自然的 志向性を「条件や結果を操作できないという前提に立ち, 予測不可能な価值を，運や偶然にゆだねて獲得する志向 性」と定義して使用する。

\section{3. 快楽的志向性と苦楽的志向性}

消費とSWB との関係を探る上では, マーケティング における満足概念が手がかりになる。Kawaguchi（2018） は，満足をプロテスタント的満足と快楽的満足とに対置 し, 識別している。プロテスタント的満足は, 「忍耐, 努 力, 労力のいずれかを必要とする行為または活動におい て非即時的に促される深い満足として」, 快楽的満足は, 「忍耐, 努力, 労力のいずれも必要としない行為または活 動において即時的に促される浅い満足として」, とらえる ことができる（Kawaguchi, 2018）。

こうした概念装置から Kawaguchi（2018）は，これま で消費者行動研究において快楽的とみなされてきた消費 の再分類を試みている。例えば，理想的に消費するため に専門知識や経験を必要とする芸術鑑賞，また車をモー タースポーツとして使用する場合などはプロテスタント 的消費に, 寒い日の一杯の温かい飲み物や温泉で癒され ること，そして車をドライブとして利用する場合は快楽 的消費に選別できる（Kawaguchi, 2018）。

ここでいうプロテスタント的消費とは,「プロテスタン トの信徒らが実践した天職や世俗内的禁欲の宗教的ない し歴史的文脈から切り離された人間行動一般の忍耐また は努力，もしくは労力をともなう消費を指している」 (Kawaguchi, 2018)。プロテスタント的消費がもたらす 「非即時的な深い満足」は, 便利で心地の良い「即時的な 満足を容認する社会」（Kawaguchi, 2018）が進展するに つれ，日本も含む西洋近代の価值観をもつ消費社会が取 りこぼしつつある満足としてとらえることができる。

本研究では, Kawaguchi（2018）の概念装置を手がか
りとして, 快楽的消費による即時的な浅い満足を志向す る心理傾向を「快楽的志向性」, プロテスタント的消費に よる非即時的な深い満足を志向する心理傾向を「苦楽的 志向性」として援用する。ここで「苦楽的」としたのは, 忍耐・努力・労力などの「苦」を通じて便益（「楽」）が 得られる側面に注目したからである。快楽的志向性とは, 「時間や労力をかけず即時的に便益を獲得する志向性」, 苦楽的志向性とは, 「忍耐・努力・労力を通じて, 非即時 的に便益を獲得する志向性」とそれぞれ定義する。

\section{4. 概念モデルの設定}

概念モデルの設定にあたり，西洋近代合理主義的なる 「作為的志向性」と西洋近代合理主義からこぼれ落ちる 「自然（じねん）的志向性」を両極においたヨコ軸を設定 する。さらに, 夕テ軸には，快楽的消費にいざなわれる 「快楽的志向性」とプロテスタント的消費にいざなわれる 「苦楽的志向性」を両極に導入することで，図 1 のよう なマトリクスが描ける。

図 1 に示したとおり，作為的一快楽的の象限をリーン 的 WB, 作為的一苦楽的の象限をエンジニアリング的 WB，自然的一快楽的の象限をセレンディピティ的 WB, 自然的一苦楽的の象限をブリコラージュ的 WB とそれぞ れ名付ける。以下に，4つの象限についての定義を行う。

（1）リーン的ウェルビーイング（WB）

Womack and Jones（2005）は, 価值提供システムの効 率化を通じ, 買いやすく, 使いやすくすることでコスト を引き下げ，時間を節約する企業が増えていると指摘す る。これにより消費者は，消費プロセスの効率化という 便益が得られる。Womack and Jones（2005）は，このよ うな消費のあり方を「リーン消費」と呼ぶ。リーン消費 の具体例として, 例えば, Amazonの顧客体験価值が挙 げられる。Kosuge（2020）によれば, Amazon は, 購買 や閲覧デー夕に基づく精度の高いレコメンドにより，消 費者個々の消費を最適化し消費を自動化する。Amazon の顧客体験価值は, 予想した流れの中で物事が進み, そ の結果も予想通りである, という予定調和である点が特 筆される (Kosuge, 2020)。リーン消費に象徴される顧客 価值のあり様は，作為的な即時性によって特徵づけられ 
出典：筆者作成

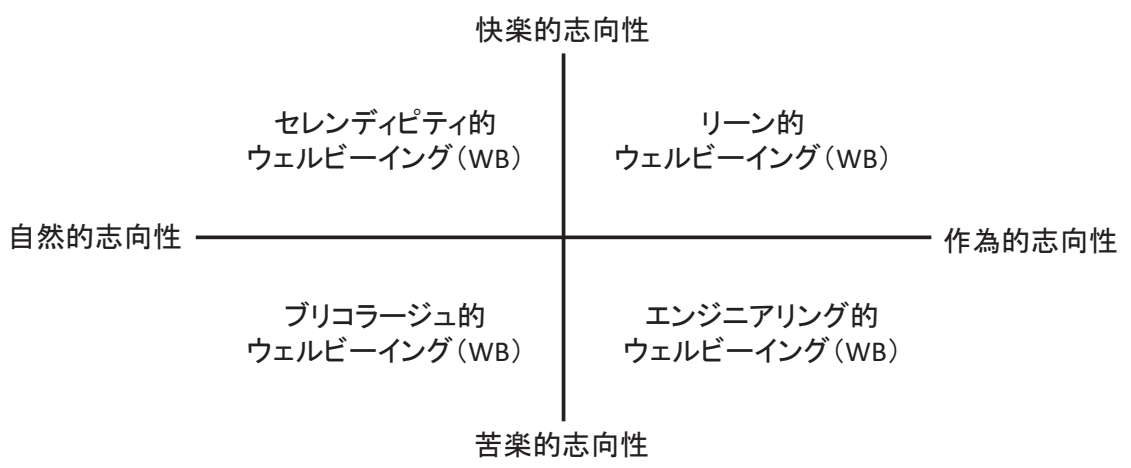

るといえる。図 1 の快楽的一作為的の象限には, こうし たリーン消費の見方を援用し，リーン的WB と名付け た。リーン的 WB とは, 「運や偶然の要素を極力排して, 目標設定された予測可能な価值を，即時的に獲得した状 態こそがWB であるとする主観的な評価」と定義する。

\section{(2) エンジニアリング的ウェルビーイング（WB）}

図 1 の作為的 - 苦楽的の象限におけるWB のあり方 は, 西洋近代合理主義にもとづき作為的でありながらも, 非即時的満足の方向, つまり苦楽的でもある。目標に向 かって計画を立て, 課題をひとつひとつ地道に克服して いく姿を想定し，この象限には，エンジニアリング的 WB と名付ける。文化人類学者レヴィ=ストロースが西 洋近代的思考をエンジニアの仕事に例えている（LéviStrauss, 1962/1976, pp. 23-26）ことからも，こうした名付 け方には妥当性があると考えられる。エンジニアリング 的 WB とは, 「目標設定された予測可能な価值を, 忍耐・ 努力・労力を通じて非即時的に，かつ意図的に獲得する プロセスや獲得した状態こそが WB であるとする主観的 な評価」と定義する。

（3）セレンディピティ的ウェルビーイング（WB）

図 1 の自然的一快楽的の象限におけるWB のあり方 は，作為のないありのままの状態や人間を自然の一部と とらえる仏教用語でいうところの自然（じねん）を志向 しつつも，快楽的消費による即時的満足の方向，つまり
快楽志向的でもある。条件・結果は操作できないという 自然（じねん）的認識を前提に, 運や偶然の要素を容認 して予測不可能な価值獲得が志向される。それに加えて, 時間や労苦を要せずに得られる「良い状態」を志向する のがこの象限の WB のあり方である。こうしたあり方 は，セレンディピティ的であるといえる。Kosuge (2020) は, 「予期せぬプロダクトやブランドとの出会いという買 い物のひとつの体験価值，すなわち醍醐味」を便益とす る「偶然出くわしたプロダクトやブランドがきっかけで 新しい未来が展開していく」ような消費をセレンディピ ティ消費と呼んでいる。自然的一快楽的の象限のWBに は, セレンディピティ的 WB と名付け，「運や偶然にゆ だねて，予測不可能な価值を即時的に獲得した状態こそ がWB であるとする主観的な評価」と定義する。

（4）ブリコラージュ的ウェルビーイング（WB）

図 1 の自然的一苦楽的の象限におけるWBのあり方 は, 自然（じねん）を志向しつつも，プロテスタント的 消費による非即時的満足の方向，つまり苦楽志向的でも ある。こうした側面を理解する補助線となるのが文化人 類学者レヴィ＝ストロースのブリコラージュ（bricolage） 概念である。

レヴィ=ストロースは, 東洋など西洋圈以外にみられ る非近代的な思考は, 実は, 西洋近代社会に生きる「文 明人」の知的作業や芸術活動にも重要な役割を果たして いると考え, これを「野生の思考」と呼んだ (Lévi-Strauss, 
1962/1976, pp. 29-38, p. 262)。「野生の思考」に対置され る「科学的思考」は, 特定の目的を効率的に達成する「栽 培思考」である（Lévi-Strauss, 1962/1976, pp. 262）。「野 生の思考」の活動形態を説明するために用いられた用語 が「ブリコラージュ」である。レヴィ＝ストロースによ れば, ブリコラージュとは計画性ではなく偶発性にもと づき，ありあわせの道具や材料を用いて自分の手でもの を作ることである（Lévi-Strauss, 1962/1976, pp. 22-28）。

ブリコラージュ的な消費の例として家庭での食事準備 が挙げられる。手元の食材や調理器具に応じて調理をし たり，遭遇した食材に応じて事後的に献立が決まったり するのがブリコラージュである（Norimoto, 2013）。一方 で, 学校や病院での給食準備はブリコラージュではない。 食材や資材の種類, 単価, 単位量あたりの栄養素量や熱 量，支出可能な予算額，調理に要する時間などが目的合 理的に検討されるからである (Norimoto, 2013)。他に も, 生け花や部屋の模様替えなどにもブリコラージュの 側面がみられる (Norimoto, 2013)。

ブリコラージュの見方によれば，あらかじめ緻密に計 画することや予定を組んで備えることの必然性はない。 むしろ計画や予定に縛られず，一つひとつの取り組みを 丁寧に積み重ねることこそが，ひいては上質な残りもの を蓄えることになり，いざというときの即興に役立つ良 き素材を提供することになる。また，そのような有り物 の中で創意工夫するというリユースの労力が，美的価值 と喜びを生み出すといえる。

図 1 の自然的-苦楽的の象限は，以上のようにブリコ ラージュ的であるとみなせる。そこで，この象限をブリ コラージュ的 WB と名付け,「運や偶然の要素を認めて, 予測不可能な価值を, 忍耐・努力・労力を通じて非即時 的に獲得するプロセスや獲得した状態こそがWBである とする主観的な評価」と定義する。

\section{III. 実証分析}

\section{1. 調査概要}

尺度項目の作成に先立ち，市場調査会社である株式会 社リサーチ・アンド・ディベロプメントのリサーチャー
10 名に協力してもらい, 2019 年 7 月 24 日, 8 月 20 日, 9 月 3 日と 3 回にわたってワークショップを開催した。 具体的には, WB と関連があると考えられる消費の具体 例を付箋に書き出していき，最終的に $\mathrm{KJ}$ 法でまとめる, という作業を行った。得られた $\mathrm{KJ}$ 法の結果は, 図 1 の モデルをベースに分類しなおし, 測定尺度項目作成の参 考とした。

測定尺度は 24 項目（1：全く当てはまらない〜 5 : 非 常に当てはまる，5段階評定尺度）が作成され，2020 年 6 月にプレ調査を行った（インターネット調查, 全国の 20 歳から 69 歳, 男性 : 937 名, 女性 936 名)。プレ調査 で得られたデー夕を因子分析により吟味し, 項目を修正 した上，最終的には測定尺度を 20 項目に絞り込み，再 度, 同年 6 月に本調査を実施した（インターネット調 查, 全国の 20 歳から 69 歳, 男性 : 926 名, 女性 : 885 名)。本調査では, 作成されたWB 尺度における外部妥 当性を確認するため, 心理学分野で使用されている SWB 尺度，および「趣味としての読書」「ゲーム」「スポーツ」 といった余暇活動の頻度についても測定された。インター ネット調査では, 株式会社クロス・マーケティングのア ンケート・パネルを利用した。

\section{2. 分析結果}

\section{（1）因子的妥当性}

本調査から得られたデー夕を使用し, 因子分析（主因 子法, プロマックス回転) を行った結果, 図 1 の概念モ デルで仮定した 4 因子構造が表 1 のとおり確認され，因 子的妥当性が認められた（分析には, SPSS Statistics ver. 25 を使用)。表 1 における第 1 因子（f1）はリーン的 WB を，第 2 因子（f2）はエンジニアリング的 WB を, 第 3 因子 (f3) はブリコラージュ的 WB を，第 4 因子 (f4) はセレンディピティ的 WB を示している。各尺度の信頼 性係数（クロンバックの $\alpha$ 係数）は，それぞれ， $\alpha=.904$, $\alpha=.867, \alpha=.857, \alpha=.897$ であった。表 1 に示した測定 尺度には「消費における主観的ウェルビーイング 4 類型尺度」(Subjective Well-Being Quaternary Scale in Consumption: SWB-QSIC）と名付けた。 


\begin{tabular}{l|r|r}
\hline & $\mathrm{f} 1$ & $\mathrm{f} 2$ \\
\hline
\end{tabular}

\begin{tabular}{ll}
\hline \multicolumn{1}{c}{ 尺度 } & AVE \\
\hline ブリコラージュ的 WB & .547 \\
エンジニアリング的 WB & .567 \\
セレンディピティ的 WB & .642 \\
リーン的WB & .655 \\
\hline
\end{tabular}

\section{（2）収束妥当性と弁別妥当性}

次に，収束妥当性および弁別妥当性を測定尺度ごとに 検討した。収束妥当性の検討には平均分散抽出度 (AVE) を用いた。AVEに関しては 0.5 以上が望ましいとされる が (Fornell \& Lacker, 1981), 全ての項目で 0.54 以上の值 であったため，十分な収束妥当性が確認されたと判断し た（表 2)。弁別妥当性に関しては，因子間相関係数の平 方と AVEの正の平方根を比較して AVEの方が大きいこ とが条件となる（Fornell \& Lacker, 1981）。分析の結果,
全ての AVE の平方根が因子間の相関係数の平方を上 回ったため, 弁別妥当性が確認されたものと判断した (表3)。

（3）既存の主観的ウェルビーイング（SWB）尺度との 関係

尺度の外的な妥当性を検討するため, 心理学分野で広 く使用されている SWB 尺度と表 - 1 で得られた 4 つの因 子との間の関連を確認した。具体的には, Diener et al. 


\begin{tabular}{lcccc}
\hline & ブリコラージュ的 & エンジニアリング的 & \multicolumn{2}{c}{ セレンディピティ的 } \\
& WB & WB & WB & .452 \\
ブリコラージュ的 WB & .739 & .446 & .219 \\
エンジニアリング的 WB & .446 & .753 & .420 \\
セレンディピティ的 WB & .452 & .420 & .801 & .338 \\
リーン的WB & .219 & .338 & .546 & .810 \\
\hline
\end{tabular}

対角線上の值：AVE の正の平方根その他の值：因子間相関係数の平方

（1985）の人生満足度尺度（SWLS）を使用して相関分析 を行った。SWLSは，西洋圈で開発された尺度であり， 学術論文への引用数が最も多い SWB 尺度の一つである (Shimai, 2015, pp. 16-18)。

分析の結果, SWLS との相関係数は, ブリコラージュ 的 WB r=.341, エンジニアリング的 WB r $=.387$, セレン デイピティ的 WB r=.229, リーン的 WB r=.209 であった (0.1\%水準ですべて有意)。この結果から, 図 1 における 快楽的志向性の象限（リーン，セレンディピティ）より も, 苦楽的志向性の象限 (エンジニアリング, ブリコラー ジュ）の方がSWLS との高い相関を示していることが分 かる。これにより SWLS は, 即時的な満足を志向する快 楽的志向性よりも非即時的な満足を志向する苦楽的志向 性との関連を強く持つ尺度であるといえる。これはSWLS が人生経験の累積的な結果（非即時的な結果）としての 満足を測定した尺度である点から妥当な結果であると解 䣋できる。また，相対的に SWLS との相関が高かった苦 楽的志向性の象限の WB では, エンジニアリング的 WB の方がブリコラージュ的 WB よりも SWLS と高い相関を 示している。これにより SWLS は, 近代合理主義的な作 為的志向性の象限に位置付けられるエンジニアリング的 WB の側面を最も強く反映する尺度であるといえる。こ のためSWLS による測定では，エンジニアリング的 WB 以外の側面を取りこぼしてしまう可能性が否定できない。 以上の分析結果により, SWB が近代合理主義的な側面 (作為的志向性)とだけ関わっているのではないという可 能性を可視化できたものと考えられる。

\section{（4）余暇活動との相関分析結果}

最後に，尺度と消費との関連を吟味するため，余㗇活
動の実施頻度（1：最近 1 年やっていない〜 9：ほぼ毎 日，9段階評定尺度）と, 表 1 の 4 因子との間で相関分 析を行った（表 4)。なお, 表 4 に示されている余暇活動 の項目は, Tachibanaki and Takamatsu（2018）を参考に作 成した。

リーン的 WB は, 「園芸・庭いじり・ガーデニング・ 日曜大工」「趣味としての料理・菓子作り」「美術鑑賞」 といった時間や労力がかかる活動において，他の WB と 比較して相関が低い傾向がみられた。即時的な満足が得 られる「ゲーム」とリーン的 WB とでは，苦楽志向的な エンジニアリング的 WB やブリコラージュ的 WB と比 べ，相関が高い傾向がみられた。

エンジニアリング的 WB は,「趣味としての読書」や 「スポーツ」といった目標設定された中での忍耐や労力を 要する活動との相関が他の WB と比較して高い傾向がみ られた。一方で, 即時的な満足が得られる「ゲーム」は, エンジニアリング的 WB との相関がもっとも低い傾向が みられた。

セレンディピティ的 WB は,「ゲーム」「音楽鑑賞」「映 画鑑賞」が他の WB と比較して相関が高い傾向がみられ た。これは, これらの活動から予測不可能な価値を即時 的に獲得できるからだと解釈できる。また，「スポーツ」 や「美術鑑賞」といった事前に努力や学習を要する活動 との相関が低い傾向もみられる。「コーラス・声楽」と 「舞踊 (邦舞, 洋舞)」は, セレンディピティ的 WB とだ け有意な負の相関がある。これはいわゆる“型”がある ものとの親和性の低さを示していると解釈できる。

ブリコラージュ的 WB は，多くの余暇活動と関連する 傾向がみられる。その中でも特筆できるのは,「演芸・演 劇・舞踊鑑賞」においてブリコラージュとの相関だけが 


\begin{tabular}{|c|c|c|c|c|}
\hline & $\begin{array}{l}\text { I) } \\
\text { ? } \\
\text { 的 } \\
\mathrm{W} \\
\mathrm{B}\end{array}$ & 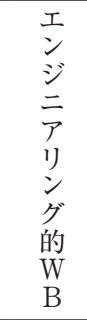 & $\begin{array}{l}\text { ブ } \\
\text { J } \\
\exists \\
\exists \\
\text { I } \\
\text { I } \\
\text { ב } \\
\text { 的 } \\
\text { W } \\
\text { B }\end{array}$ & 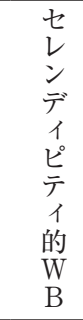 \\
\hline 趣味としての読書 & $149^{* *}$ & $.222^{* *}$ & $.185^{* *}$ & $.176^{* *}$ \\
\hline $\begin{array}{l}\text { ゲーム } \\
\text { (家でするゲーム, スマートフォン } \\
\text { 用含む) }\end{array}$ & $152^{* *}$ & $.095^{* *}$ & $.130^{* *}$ & $.187^{* *}$ \\
\hline $\begin{array}{l}\text { スポーツ } \\
(\text { テニス・水泳・登山・ゴルフなど })\end{array}$ & $104^{* *}$ & $.159^{* *}$ & $.114^{* *}$ & $.085^{* *}$ \\
\hline $\begin{array}{l}\text { ギャンブル } \\
(\text { パチンコ・競馬・競輪など) }\end{array}$ & .028 & -.021 & .024 & -.015 \\
\hline カラオケ & $083^{* *}$ & $.047^{*}$ & $.074^{* *}$ & $.053^{*}$ \\
\hline $\begin{array}{l}\text { 園芸・庭いじり・ガーデニング・ } \\
\text { 日曜大工 }\end{array}$ & $.048^{*}$ & $.188^{* *}$ & $.164^{* *}$ & $.102^{* *}$ \\
\hline 趣味としての料理・菓子作り & $.093^{* *}$ & $.182^{* *}$ & $.186^{* *}$ & $.119^{* *}$ \\
\hline 和裁・洋裁・手芸 & .040 & $.089^{* *}$ & $.098^{* *}$ & $.053^{*}$ \\
\hline スポーツ鑑賞 & $101^{* *}$ & $.140^{* *}$ & $.135^{* *}$ & $.106^{* *}$ \\
\hline 映画鑑賞 & $164^{* *}$ & $.179^{* *}$ & $.136^{* *}$ & $.150^{* *}$ \\
\hline
\end{tabular}

**: $1 \%$ 水準で有意, *: $5 \%$ 水準で有意。

有意に確認された点である。これは，教養を身につける という「忍耐・努力・労力」を通じて初めて，予期せ女 物語展開を楽しむことができる性質が「演芸・演劇・舞 踊鑑賞」にあるためと考えられる。

以上のように 4 つの WB の側面は，余㗇行動という消 費側面との多様な関連性を示していることが分かる。こ の点から, 本研究の提案した尺度によって消費をより多 面的に分析する上での有用性が示されたといえる。

\section{IV. おわりに}

本研究では, 西洋的な近代合理主義から捨象された WB の側面とその側面に関わる消費の側面を取り入れた 新たな WB 尺度を提案することを目的としていた。ブリ コラージュ，エンジニアリング，セレンディピティ,リー ンの 4 つのコンセプトからなる概念モデルを提案した上 で測定尺度の開発を行い，「消費における主観的ウェル ビーイングの 4 類型尺度（SWB-QSIC)」と名付けた。当

\begin{tabular}{|c|c|c|c|c|}
\hline & $\begin{array}{l}\text { J } \\
\text { l } \\
\text { v } \\
\text { 的 } \\
\mathrm{W} \\
\mathrm{B}\end{array}$ & 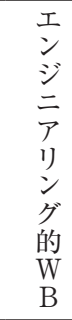 & $\begin{array}{l}\text { ブ } \\
\text { リ } \\
\exists \\
\bar{J} \\
1 \\
\text { I } \\
\text { ב } \\
\text { 的 } \\
\text { W } \\
\text { B }\end{array}$ & $\begin{array}{l}セ \\
レ \\
\text { テ } \\
\text { デ } \\
\text { ヒ́ } \\
\text { テ } \\
\text { 1 } \\
\text { 的 } \\
\text { W } \\
\text { B }\end{array}$ \\
\hline 音楽鑑賞 & $163^{* *}$ & $201^{* *}$ & $.169^{* *}$ & $.210^{* *}$ \\
\hline 美術鑑賞 & .032 & $.104^{* *}$ & $.110^{* *}$ & $.053^{*}$ \\
\hline 遊園地・動植物園・水族館等の見物 & $.078^{* *}$ & $.092^{* *}$ & $.117^{* *}$ & $.091^{* *}$ \\
\hline 演芸・演劇・舞踊鑑賞 & .022 & .034 & $.055^{*}$ & .005 \\
\hline 楽器の演奏 & $061^{* *}$ & .040 & $.071^{* *}$ & .037 \\
\hline 絵画・彫刻などの制作 & .033 & $-.050^{*}$ & .011 & $-.052^{*}$ \\
\hline コーラス・声楽 & .022 & -.041 & .019 & $-.048^{*}$ \\
\hline 詩・和歌・俳句・小説などの制作 & .004 & -.026 & -.008 & -.044 \\
\hline 書道・華道・茶道 & .009 & -.023 & .016 & -.041 \\
\hline 舞踊 (邦舞, 洋舞) & .026 & -.041 & .004 & $-.059^{*}$ \\
\hline
\end{tabular}

然，我々日本人が「近代化」された社会に生活している 以上，その消費の在り方も近代合理主義的な思考の枠組 みから自由ではない。これは，近代合理主義的なるもの とそうではないものとを厳密に弁別することの困難さを 意味する。そうした前提を踏まえながらも，本研究では， 自然（じねん）的視点から非近代合理主義的な WB の側 面を把握するべく検討を行った。北米を中心とする西欧 圈で検討された WB 測定尺度が主流を占める中, 非西洋 近代合理主義的な要素も含んだ消費側面におけるWB 尺 度を提案した点に扔いて, 本研究では, マーケティング と幸福に関わる研究に新たな視座を提供できたものと考 えられる。

また，本研究で開発された尺度を実務的に活用するこ とも可能である。我が国の消費とWB の関連について, 既存の WB 尺度では把握できなかった新たな発見を提供 できる可能性がある。例えば，自社製品の顧客価值がい かなるタイプの WB 側面と関連しているのかを把握する ことができるだろう。一方で，開発された尺度と消費と の関連においては, 一般的な余㗇活動の実施頻度との関 
連において吟味したに過ぎない。今後は，より具体的な 消費の側面との関連を確認し，検証事例を経験的に積み 上げていく必要がある。

\section{謝辞}

本稿の執筆にあたり，匿名のレビュアーの先生からは 懇切なご指導を賜りました。また，日本マーケティング 学会カンファレンス 2020 オーラルセッション（2020 年 10 月 18 日, 於法政大学, オンライン開催）において, 本稿の元になる研究報告を行った際には, コメンテーター の新倉貴士先生（法政大学）より有益なコメントを賜り ました。この場をお借りして心より感謝申し上げます。

\section{References}

Devezer, B., Sprott, D. E., Spangenberg, E. R., \& Czellar, S. (2014). Consumer well being: Effects of subgoal failures and goal importance. Journal of Marketing, 78(March), 118-134.

Diener, E., Emmons, R. A., Larsen, R. J., \& Griffin, S. (1985). The satisfaction with life scale. Journal of Personality Assessment, 49(1), 71-75.

Diener, E., Oishi, S., \& Lucas, R. E. (2003). Personality, culture, and subjective well-being: Emotional and cognitive evaluations of life. Annual Review of Psychology, 54, 403-425.

Fornell, C., \& Larcker, D. F. (1981). Evaluating structural equation models with unobservable variables and measurement error. Journal of Marketing Research, 18(1), 39-50.

Horige, K. (2019). Positive na kokoro no kagaku: Hito to syakai no yoriyoi kakawari wo mezashite. Tokyo: Saiensu-sha. (堀毛一也 (2019).『ポジティブなこころの科学一人と社会のよりよい 関わりをめざして一』サイエンス社) (In Japanese)

Kawaguchi, T. (2018). Kachikyoso jidai ni okeru marketing no kanosei: Syohi to seisan no aratana kankei. Kyoto: Minervashobo．(川口高弘 (2018)。『価值共創時代における マーケティングの可能性一消費と生産の新たな関係一』ミ ネルヴァ書房) (In Japanese)

Kimura, S. (n.d). Seikatsu no naka no bukkyo yogo 244 jinen. Otani University. Retrieved from http://www.otani.ac.jp/yomu page/b yougo/nab3mq0000000ro3.html (August 6, 2020). ( 木 村宣彰 (n.d.).「生活の中の仏教用語 244 自然」『大谷大学』) (In Japanese)

Kitayama, S. (2012). Kojinsyugi to kofuku: Uchida, Ogihara ronbun eno comment. Japanese Psychological Review, 55(1), 43-46. (北 山忍（2012）。「個人主義と幸福一内田・荻原論文へのコメ ントー」『心理学評論』55(1), 43-46) (In Japanese)

Kosuge, R. (2020). Amazon ni taikosiuru serendipity syohi no sosyutsu. Senndennkaigi, May.（小菅竜介（2020）。「Amazon に対抗し得る「セレンディピティ消費」の創出」『宣伝会 議』5 月号) (In Japanese)

Lévi-Strauss, C. (1962). LA PENSÉE SAUVEGE. Paris: Librairie
Plon.（大橋保夫（訳）（1976）、『野生の思考』みすず書房） Norimoto, H. (2013). Development of meanings of things by "Bricolage" actions. Bulletin of the Faculty of Education, Mie University, 64, 159-167. (乘本秀樹（2013).「「ブリコラー ジュ」による物の意味の展開」『三重大学教育学部研究紀要 教育科学』64, 159-167）(In Japanese with English abstract)

Oishi, S., \& Komiya, A. (2012). Is it possible to compare happiness across cultures? Psychological Review, 55(1), 6-21.（大石繁 宏・小宮あすか (2012).「幸せの文化比較は可能か？」『心 理学評論』55(1), 6-21) (In Japanese with English abstract)

Shimai, S. (2015). Happiness: Science \& Practice. Tokyo: Yuhikaku. （島井哲志 (2015)。『幸せの構造一持続する幸福感と幸せな 社会づくり』有斐閣）(In Japanese)

Tachibanaki, T., \& Takamatsu, R. (2018). Kofukukan no tokeibunseki. Tokyo: Iwanami Shoten.（橘木俊詔 - 高松里江（2018）。『幸 福感の統計分析』岩波書店）(In Japanese)

Uchida, Y., \& Ogihara, Y. (2012). Cultural construal of happiness: Cultural psychological perspectives and future direction of happiness research. Japanese Psychological Review, 55(1), 2642. (内田由紀子 - 荻原祐二 (2012).「文化的幸福観一文化 心理学的知見と将来への展望一」『心理学評論』55(1), 2642) (In Japanese with English abstract)

Womack, J. P., \& Jones, D. T. (2005). Lean consumption. Harvard Business Review, 83(March), 58-68. 